\title{
KARAKTERISTIK FISIKOKIMIA DAN ORGANOLEPTIK FOOD BARS LABU KUNING (Cucurbita máxima) DENGAN PENAMBAHAN TEPUNG KEDELAI DAN TEPUNG KACANG HIJAU SEBAGAI ALTERNATIF PRODUK PANGAN DARURAT
}

\author{
PHYSICOCHEMICAL AND ORGANOLEPTIC CHARACTERISTIC OF PUMPKIN \\ (Cucurbita maxima) FOOD BARS SUPLEMENTED WITH SOY BEAN FLOUR AND MUNG \\ BEAN FLOUR AS EMERGENCY FOOD PRODUCT
}

Roifah Fajri *), Basito*), Dimas Rahadian Aji Muhammad ${ }^{*}$
${ }^{*}$ Program Studi Ilmu dan Teknologi Pangan, Universitas Sebelas Maret

Email: rahadiandimas@yahoo.com

\begin{abstract}
The aim of this research were to determine the formulation, to find out the physicochemical and organoleptic characteristic of pumpkin food bars added with soy bean flour and mung bean flour so that it will meet the nutrition requirement of emergency food product, and to determine which pumpkin food bars has the highest consumer's acceptance rate. In this research, completely randomized design was used with one factor i.e., ratio of addition soy bean flour and mung bean flour 0:1, 3:1, 1:1, 1:3, dan 1:0. The result of the research showed that pumpkin food bars which met the nutrition requirement of emergency food product and had the highest consumer's acceptance rate was pumpkin food bar with ratio addition of soy bean flour and mung bean flour 1:0. It contained 31,25\% pumpkin flour; 13,02\% full cream milk powder; 7,81\% sugar; 14,06\% margarine; 13,02\% water; and 20,83\% soy bean flour. It also contained 14,76\% water; 4,28\% ash; 14,31\% protein ; 19,87\% fat; and 46,78\% carbohydrate with 211,56 kcal total calorie consist of 13,52\% protein; 42,22\% fat; and 44,26\% carbohydrate. Based on organoleptic analysis, pumpkin food bar with ratio addition of soy bean flour and mung bean flour 1:0 had dark colour, did not have any "langu" taste or flavor, had pretty tender texture, and did not have "langu" aftertaste.
\end{abstract}

Keywords: emergency food product, food bars, mung bean flour, pumpkin flour, soy bean flour

\section{ABSTRAK}

Penelitian ini bertujuan untuk mengetahui formulasi serta karakteristik fisikokimia dan organoleptik food bars berbahan dasar labu kuning dengan penambahan tepung kedelai dan tepung kacang hijau yang memenuhi standar gizi pangan darurat dan memiliki tingkat penerimaan konsumen paling tinggi. Dalam penelitian ini digunakan rancangan acak lengkap dengan satu faktor yaitu penambahan tepung kedelai dan tepung kacang hijau dengan perbandingan $0: 1,3: 1,1: 1,1: 3$, dan 1:0. Hasil penelitian menunjukkan bahwa food bars labu kuning yang memenuhi standar gizi pangan darurat dan memiliki tingkat penerimaan konsumen paling tinggi adalah food bars labu kuning dengan perbandingan penambahan tepung kedelai dan kacang kacang hijau 1:0 dengan komposisi tepung labu kuning 31,25\%, susu bubuk full cream 13,02\%, gula pasir 7,81\%, margarin 14,06\%, air 13,02\% dan tepung kedelai 20,83\%. Food bars tersebut memiliki kadar air 14,76\%; kadar abu 4,28\%; kadar protein 14,31\%; kadar lemak 19,87\%; dan kadar karbohidrat 46,78\% dengan total kalori sebesar $211,56 \mathrm{kkal}$ yang terdiri dari 13,52\% protein; 42,22\% lemak; dan 44,26\% karbohidrat. Berdasarkan analisis organoleptik, food bars labu kuning dengan perbandingan penambahan tepung kedelai dan tepung kacang hijau 1:0 memiliki warna gelap, tidak ada rasa dan aroma langu, memiliki tekstur yang tidak terlalu keras serta tidak mempunyai aftertaste langu.

Kata kunci : food bars, pangan darurat, tepung labu kuning, tepung kedelai, tepung kacang hijau

\section{PENDAHULUAN}

Pangan darurat (emergency food product) merupakan produk pangan olahan yang dirancang khusus untuk dikonsumsi pada kondisi yang menyebabkan manusia tidak dapat hidup dengan normal, misalnya kondisi pasca bencana. Pada kondisi tersebut dimungkinkan adanya kerusakan infrastruktur yang menyebabkan korban kesulitan memenuhi kebutuhan pangannya.
Produk pangan darurat dapat diberikan kepada korban bencana alam selama 15 hari sampai adanya bantuan yang lebih memadai. Produk pangan darurat harus dapat memenuhi kebutuhan energi minimal yaitu 2100 kkal per hari dan dapat dikonsumsi oleh berbagai kalangan usia (Zoumas et al., 2002).

Pengembangan produk pangan darurat dapat dilakukan dengan mereformulasi produk pangan sehingga memenuhi syarat pangan darurat. Salah satu 
jenis pangan yang dapat dikembangkan sebagai pangan darurat adalah food bars. Menurut Widjanarko (2008), food bars dibuat dari campuran bahan pangan (blended food) yang diperkaya dengan nutrisi yang kemudian dibentuk menjadi bentuk padat dan kompak (a food bar form). Meskipun berbentuk padat dan kompak, food bars merupakan jenis makanan semi basah (intermediate moisture food) sehingga lebih tahan terhadap tekanan daripada produk kering seperti cookies. Kelebihan ini membuat food bars lebih mudah diangkut atau dikirim ke daerah bencana sehingga bisa dijadikan alternatif produk pangan darurat. Selain itu, food bars mempunyai kadar air yang cukup sehingga mudah ditelan tanpa menimbulkan sensasi kering namun tetap stabil selama penyimpanan.

Salah satu bahan pangan lokal yang dapat dimanfaatkan dalam pembuatan produk pangan darurat adalah labu kuning (Cucurbita maxima). Labu kuning dikenal sebagai bahan pangan yang banyak mengandung karoten sebagai sumber vitamin A. Menurut Widowati, dkk (2010), kandungan karbohidrat dalam tepung labu kuning mencapai $77,65 \%$, sehingga tepung labu kuning dapat digunakan sebagai alternatif sumber karbohidrat. Dalam pembuatan produk pangan darurat, terdapat standar gizi yang harus dipenuhi. Oleh karena itu diperlukan penambahan sumber protein agar standar gizi yang ditentukan dapat terpenuhi. Kacang kedelai dan kacang hijau merupakan dua jenis kacang-kacangan yang memiliki kandungan protein cukup tinggi dan mudah ditemukan hampir di seluruh wilayah Indonesia. Menurut Astawan (2009), kacang kedelai mempunyai kandungan protein 46,2\% serta kaya akan isoflavon. Sedangkan kacang hijau memiliki kandungan protein $20-25 \%$ dan karbohidrat lebih dari 55\%. Pada penelitian ini akan dikaji lebih lanjut mengenai perbandingan penggunaan tepung kedelai dan tepung kacang hijau, sifat fisikokimia dan sifat organoleptik dari foodbars labu kuning dengan penambahan sumber protein berupa tepung kacang kedelai dan tepung kacang hijau.

\section{METODE PENELITIAN}

\section{Bahan dan Alat}

Bahan yang digunakan dalam pembuatan food bars labu kuning adalah tepung labu kuning, tepung kedelai, tepung kacang hijau, susu full cream, gula pasir, margarin, dan air. Sedangkan bahan kimia yang digunakan dalam analisis adalah larutan $\mathrm{H}_{2} \mathrm{SO}_{4}$ pekat, larutan $\mathrm{NaOH} 30 \%$, larutan asam borat $3 \%$, larutan $\mathrm{HCl}$, indikator $\mathrm{MR}$ dan BCG dan larutan petroleum ether.

Mesin pengiris, mesin pengering kabinet, blender, mesin pengayak, mesin penggiling, timbangan analitik, loyang pencetak, oven, desikator, tanur, alat kjeldahl, alat soxhlet dan texture analyzer.

\section{Tahapan Penelitian \\ Pembuatan Tepung Labu Kuning}

Labu kuning dikupas dan dibersihkan dari biji dan jonjot daging buah. Setelah itu buah labu kuning yang sudah bersih dipotong dengan ketebalan 2-3 $\mathrm{mm}$ dan diblanching selama 5 menit. Setelah itu dilakukan pengeringan selama 11 jam pada suhu 60-70 ${ }^{\circ} \mathrm{C}$. Labu kuning yang sudah kering kemudian dihancurkan menggunakan blender dan diayak menggunakan ayakan 60 mesh.

\section{Pembuatan Tepung Kedelai}

Biji kedelai disortasi dari tangkai dan kotoran kemudian dikeringkan dalam oven selama 2-3 jam dengan suhu 50-60 ${ }^{\circ} \mathrm{C}$. Sebelum digiling, kulit biji kedelai dikupas terlebih dahulu menggunakan grinder. Setelah dikupas, kulit biji kedelai kemudian dipisahkan dari daging bijinya dengan cara ditampi manual. Biji kedelai yang telah bersih dari kulitnya kemudian digiling dan diayak menggunakan ayakan 60 mesh.

\section{Pembuatan Tepung Kacang Hijau}

Biji kacang hijau disortasi dari tangkai dan kotoran kemudian dikeringkan dalam oven selama 2-3 jam dengan suhu 50$60{ }^{\circ} \mathrm{C}$. Setelah itu biji kacang hijau dikupas menggunakan grinder kemudian ditampi secara manual untuk menghilangkan kulit biji kacang hijau. Biji kacang hijau yang telah bersih dari kulitnya kemudian digiling dan diayak menggunakan ayakan 60 mesh. 


\section{Penentuan Formulasi Produk}

Formulasi produk food bars labu kuning mengacu pada pemenuhan standar makronutrien pangan darurat yang dikeluarkan oleh Institute of Medicine dalam Zoumas et al. (2002) yaitu protein 10-15\%, lemak $35-45 \%$ dan karbohidrat $40-50 \%$ dari total kalori. Untuk mendapatkan produk yang memenuhi standar tersebut, dilakukan perhitungan formulasi berdasarkan komposisi makronutrien dari masing-masing bahan yang digunakan dalam pembuatan food bars labu kuning. Nilai makronutrien masingmasing bahan yang digunakan dalam pembuatan food bars labu kuning ditunjukkan pada Tabel 1.

Tabel 1 Nilai Makronutrien Bahan yang Digunakan dalam Pembuatan Food Bars Labu Kuning

\begin{tabular}{|c|c|c|c|}
\hline \multirow[t]{2}{*}{ Bahan } & \multicolumn{3}{|c|}{$\begin{array}{l}\text { Makronutrien } \\
\text { (g/100 g bahan) }\end{array}$} \\
\hline & Protein & Lemak & $\begin{array}{l}\text { Karbohi } \\
\text { drat }\end{array}$ \\
\hline $\begin{array}{l}\text { Tepung Labu } \\
\text { Kuning }^{\text {a }}\end{array}$ & 10,5 & 3,1 & 71,67 \\
\hline $\begin{array}{l}\text { Susu Full } \\
\text { Cream }^{\text {b }}\end{array}$ & 27 & 26 & 40 \\
\hline Gula pasir $^{b}$ & 0 & 0 & 94 \\
\hline Margarin ${ }^{b}$ & 0,5 & 81,6 & 1,4 \\
\hline Air & 0 & 0 & 0 \\
\hline $\begin{array}{l}\text { Tepung } \\
\text { Kedelai }^{\mathrm{a}}\end{array}$ & 31,32 & 20,36 & 35,9 \\
\hline $\begin{array}{l}\text { Tepung } \\
\text { Kacang Hijau }^{a}\end{array}$ & 22,66 & 1,07 & 63,71 \\
\hline
\end{tabular}

Data nilai makronutrien masingmasing bahan tersebut kemudian dijadikan acuan dalam menentukan komposisi dari formulasi yang akan diteliti seperti ditunjukkan pada Tabel 2. Penggunaan tepung kedelai : tepung kacang hijau yang akan digunakan pada penelitian ini adalah 0:1 (F1), 1:3 (F2), 1:1 (F3), 3:1 (F4), 1:0 (F5). Nilai total kalori diperoleh dengan menjumlahkan nilai kalori makronutrien masing-masing formulasi. Setiap gram protein dan karbohidrat mengandung kalori sebesar 4 kkal sedangkan satu gram lemak mengandung kalori sebesar 9 kkal (Gaman dan Sherrington, 1992). Prediksi kecukupan nutrisi food bars labu kuning dapat dilihat pada Tabel 3.

\section{Pembuatan Food Bars}

Tepung labu kuning, margarin, gula, susu, tepung kedelai, tepung kacang hijau dicampur menggunakan mixer hingga terbentuk adonan yang kalis. Adonan kemudian dicetak dalam loyang yang sudah dioles margarin dan dipanggang dalam oven dengan suhu $120{ }^{\circ} \mathrm{C}$ selama 45 menit. Food bars yang telah matang kemudian dikeluarkan dari loyang dan didinginkan.

\section{Analisis Fisikokimia dan Organoleptik}

Analisis fisikokimia terdiri dari analisis tekstur menggunakan texture analyzer, analisis kadar air dengan metode thermogravimetri (Sudarmadji dkk., 1989), analisis kadar abu dengan metode cara kering (Sudarmadji dkk., 1989), analisis kadar protein dengan metode kjeldahl (Sudarmadji dkk., 1989), analisis kadar lemak dengan metode ekstraksi soxhlet (Tejasari, 2005), dan analisis kadar karbohidrat dengan metode carbohydrate by different (Tejasari, 2005). Analisis Organoleptik terdiri dari uji kesukaan (Setyaningsih dkk., 2010) terhadap parameter warna, aroma, rasa, tekstur, dan overall serta uji pembedaan (Setyaningsih dkk., 2010) terhadap parameter aftertaste langu.

\section{HASIL DAN PEMBAHASAN}

\section{Karakteristik Fisikokimia Food Bars Labu Kuning}

\section{Tekstur}

Pada Tabel 4, sampel F1 memiliki tingkat kekerasan paling rendah dan berbeda nyata dibandingkan dengan keempat sampel yang lain. Tingkat kekerasan paling tinggi ditunjukkan oleh sampel F4 dan tidak berbeda nyata jika dibandingkan dengan sampel F3 dan F5. Sedangkan sampel F2 tidak berbeda nyata jika dibandingkan dengan sampel F3 dan F5 namun berbeda nyata jika dibandingkan dengan sampel F1 dan F5. 
Tabel 2 Formulasi Awal Food Bars Labu Kuning

\begin{tabular}{lrrrrr}
\hline \multirow{2}{*}{ Bahan } & \multicolumn{5}{c}{ Komposisi (\%) } \\
\cline { 2 - 6 } & F1 & F2 & F3 & F4 & \multicolumn{1}{c}{ F5 } \\
\hline Tepung labu kuning & 28,25 & 31,25 & 31,25 & 31,25 & 31,25 \\
Susu full cream & 14,12 & 13,02 & 13,02 & 13,02 & 13,02 \\
Gula pasir & 5,65 & 7,81 & 7,81 & 7,81 & 7,81 \\
Margarin & 15,25 & 14,06 & 14,06 & 14,06 & 14,06 \\
Air & 14,12 & 13,02 & 13,02 & 13,02 & 13,02 \\
Tepung kedelai & 0,00 & 5,21 & 10,42 & 15,63 & 20,83 \\
Tepung kacang hijau & 22,60 & 15,63 & 10,42 & 5,21 & 0,00 \\
\hline
\end{tabular}

Tabel 3 Prediksi Kecukupan Nutrisi Food Bars Labu Kuning

\begin{tabular}{lccrr}
\hline Formula & $\begin{array}{c}\text { Protein } \\
(\%)\end{array}$ & $\begin{array}{c}\text { Lemak } \\
(\%)\end{array}$ & $\begin{array}{c}\text { Karbohidrat } \\
(\%)\end{array}$ & \multicolumn{1}{c}{$\begin{array}{c}\text { Total Kalori } \\
(\mathrm{kkal})\end{array}$} \\
\hline F1 & 12,40 & 40,16 & 47,44 & 204,54 \\
F2 & 12,36 & 39,41 & 48,23 & 204,17 \\
F3 & 12,66 & 41,19 & 46,14 & 206,61 \\
F4 & 12,95 & 42,94 & 44,11 & 209,04 \\
F5 & 13,24 & 44,63 & 42,13 & 211,47 \\
\hline
\end{tabular}

Tabel 4 Hasil Analisis Tekstur Food Bars Labu Kuning

\begin{tabular}{ll}
\hline Sampel & Fmax $(\mathrm{N})$ \\
\hline F1 $(0: 1)^{*}$ & $13,84^{\mathrm{a}}$ \\
F2 $(1: 3)^{*}$ & $18,51^{\mathrm{b}}$ \\
$\mathrm{F} 3(1: 1)^{*}$ & $20,10^{\mathrm{bc}}$ \\
$\mathrm{F} 4(3: 1)^{*}$ & $24,15^{\mathrm{c}}$ \\
$\mathrm{F} 5(1: 0)^{*}$ & $20,95^{\mathrm{bc}}$ \\
\hline Keterangan : & nilai yang diikuti oleh huruf yang \\
& berbeda menunjukkan nilai yang \\
& berbeda nyata pada taraf signifikansi \\
& 0,05 \\
& $*=$ Penambahan tepung kedelai : \\
& tepung kacang hijau
\end{tabular}

Dalam penelitian ini, diduga kandungan polisakarida pada masing-masing sampel tidak berbeda secara signifikan. Sampel F1 memiliki kandungan protein paling rendah dan diduga memiliki interaksi protein dan polisakarida yang paling sedikit sehingga memiliki tingkat kekerasan yang paling rendah pula. Hal ini disebabkan pada sampel F1 hanya digunakan tepung kacang hijau yang mempunyai kandungan protein lebih rendah dibandingkan tepung kedelai.

\section{Komposisi Kimia Food Bars Labu Kuning} Kadar Air

Pada Tabel 5, kadar air sampel F5 memiliki nilai paling rendah dan berbeda nyata dengan sampel F2 dan F3. Hal ini disebabkan karena tepung kedelai yang digunakan dalam sampel F5 memiliki kadar air yang lebih kecil daripada kadar air pada tepung kacang hijau yang digunakan pada sampel F1, F2, F3, dan F4. Kadar air pada tepung kedelai adalah 7,78\% dan kadar air pada tepung kacang hijau adalah 9,66\%. Menurut Shemilt (1983), produk IMF memiliki kadar air sekitar 10-40\% dengan nilai aktifitas air $\left(\mathrm{a}_{\mathrm{w}}\right)$ 0,6-0,9. Kelima sampel food bars labu kuning memiliki nilai kadar air (\% wb) sebesar 14,76-16,66\%, sehingga dapat disimpulkan bahwa kelima sampel food bars labu kuning yang dianalisis memenuhi kriteria kadar air produk IMF.

\section{Kadar Abu}

Kadar abu menunjukkan kandungan mineral yang terdapat dalam suatu bahan (Sudarmadji dkk., 1989). Pada Tabel 5, kadar abu pada kelima sampel tidak berbeda nyata yaitu 4,10 - 4,28 \%. Hal ini berarti penambahan tepung kacang hijau dan tepung kedelai tidak berpengaruh terhadap 
Tabel 5 Hasil Analisis Kimia Food Bars Labu Kuning

\begin{tabular}{llllll}
\hline Sampel & $\begin{array}{l}\text { Air } \\
(\% \mathrm{wb})\end{array}$ & $\begin{array}{l}\text { Abu } \\
(\% \mathrm{wb})\end{array}$ & $\begin{array}{l}\text { Protein } \\
(\% \mathrm{wb})\end{array}$ & $\begin{array}{l}\text { Lemak } \\
(\% \mathrm{wb})\end{array}$ & $\begin{array}{l}\text { Karbohidrat } \\
(\% \mathrm{wb})\end{array}$ \\
\hline F1 $(0: 1)^{*}$ & $15,12^{\mathrm{ab}}$ & $4,05^{\mathrm{a}}$ & $12,03^{\mathrm{a}}$ & $19,44^{\mathrm{ab}}$ & $49,36^{\mathrm{a}}$ \\
F2 $(1: 3)^{*}$ & $16,65^{\mathrm{b}}$ & $4,07^{\mathrm{a}}$ & $12,42^{\mathrm{ab}}$ & $18,28^{\mathrm{a}}$ & $48,59^{\mathrm{a}}$ \\
F3 $(1: 1)^{*}$ & $16,65^{\mathrm{b}}$ & $4,10^{\mathrm{a}}$ & $13,16^{\mathrm{bc}}$ & $19,30^{\mathrm{ab}}$ & $46,79^{\mathrm{b}}$ \\
F4 $(3: 1)^{*}$ & $16,14^{\mathrm{ab}}$ & $4,28^{\mathrm{a}}$ & $14,06^{\mathrm{cd}}$ & $19,84^{\mathrm{b}}$ & $45,68^{\mathrm{b}}$ \\
F5 $(1: 0)^{*}$ & $14,76^{\mathrm{a}}$ & $4,28^{\mathrm{a}}$ & $14,31^{\mathrm{d}}$ & $19,87^{\mathrm{b}}$ & $46,78^{\mathrm{b}}$ \\
\hline
\end{tabular}

Keterangan : Nilai yang diikuti oleh huruf yang berbeda pada kolom yang sama menunjukkan nilai yang berbeda nyata pada taraf signifikansi 0,05

* = Penambahan tepung kedelai : tepung kacang hijau

kandungan mineral pada food bars labu kuning.

\section{Kadar Lemak}

Pada Tabel 5, Nilai kadar lemak paling rendah dimiliki oleh sampel F2 yaitu food bars labu kuning dengan penambahan tepung kedelai dan tepung kacang hijau dengan perbandingan 1:3. Hal ini disebabkan karena kadar lemak pada tepung kedelai lebih besar yaitu 20,6\% (Nio, 1992) dari pada kadar lemak pada tepung kacang hijau yaitu sebesar 0,8 \% (Astawan, 2009).

\section{Kadar Protein}

Tabel 5 menunjukkan sampel yang memiliki kadar protein paling rendah adalah sampel F1 yaitu food bars labu kuning dengan penambahan tepung kacang hijau, sedangkan sampel yang memiliki kandungan paling tinggi adalah sampel F5 yaitu food bars labu kuning dengan penambahan tepung kedelai. Hal ini disebabkan karena kadar protein pada tepung kedelai lebih besar yaitu 35,9\% (Nio, 1992) daripada kadar protein pada tepung kacang hijau yaitu sebesar 20,15\% (Astawan, 2009).

\section{Kadar Karbohidrat}

Tabel 5 menunjukkan bahwa kadar karbohidrat yang paling tinggi dimiliki oleh sampel F1 yaitu 49,36\% dan nilai kadar karbohidrat paling rendah dimiliki oleh sampel F4 yaitu 45,68\%. Dalam penelitian ini, analisis kadar karbohidrat dilakukan dengan metode by different sehingga nilai yang dihasilkan tergantung pada jumlah komponen lain dalam food bars labu kuning. Dari hasil analisis statistik diketahui bahwa sampel F1 dan F2 berbeda nyata dengan sampel F3, F4 dan F5. Hal ini disebabkan karena pada sampel F1 dan F2 proporsi penggunaan tepung kacang hijau lebih banyak daripada tepung kedelai. Kadar karbohidrat tepung kedelai lebih rendah yaitu 29,9\% (Nio, 1992) daripada kadar karbohidrat tepung kacang hijau yaitu 69,71\% (Astawan, 2009).

Pada susu bubuk yang digunakan dalam pembuatan food bars labu kuning terdapat kandungan laktosa yang penggunaannya harus dibatasi. Zoumas et al. (2002) menyebutkan bahwa kandungan laktosa dalam produk pangan darurat tidak boleh lebih dari 17 g/1000 kkal. Kadar laktosa yang terdapat dalam produk food bars labu kuning adalah 11,44-12,50 g/1000 kkal sehingga masih berada dalam batas yang diperbolehkan.

\section{Total Energi Food Bars Labu Kuning}

Berdasarkan faktor Atwater, karbohidrat dapat menghasilkan $4 \mathrm{kkal} / \mathrm{g}$, lemak $9 \mathrm{kkal} / \mathrm{g}$ dan protein $4 \mathrm{kkal} / \mathrm{g}$ (Robinson, 1975). Pada , kelima sampel food bars labu kuning telah memenuhi standar gizi pangan darurat.

\section{Karakteristik Organoleptik Food Bars Labu Kuning}

\section{Warna}

Tabel 7 menunjukkan tingkat kesukaan terhadap parameter warna paling tinggi dimiliki oleh sampel F5. Tingkat kesukaan terhadap parameter warna sampel F5 berbeda nyata dibanding keempat sampel lainnya. Hal ini menunjukkan bahwa panelis lebih menyukai warna food bars labu kuning yang lebih gelap. Warna sampel F5 
Tabel 6 Sumbangan Kalori Makronutrien dan Total Kalori Food Bars Labu Kuning

\begin{tabular}{ccccc}
\hline $\begin{array}{c}\text { Sampel } \\
\text { Food Bars } \\
\text { Labu Kuning }\end{array}$ & \multicolumn{2}{l}{ Sumbangan Kalori Makronutrien (\%) } & \multirow{2}{*}{$\begin{array}{c}\text { Total Kalori } \\
\text { (kkal/ 50 g bar) }\end{array}$} \\
\cline { 2 - 3 } Standar & Lemak & Karbohidrat & \\
Pangan & $10-15^{\mathrm{a}}$ & $35-45^{\mathrm{a}}$ & $40-50^{\mathrm{a}}$ & $175-233^{\mathrm{b}}$ \\
Darurat & & & & \\
\hline F1 $(0: 1)^{*}$ & 11,44 & 41,61 & 46,95 & 210,26 \\
F2 $(1: 3)^{*}$ & 12,16 & 40,26 & 47,58 & 204,25 \\
F3 (1:1)* & 12,73 & 42,00 & 45,27 & 206,74 \\
F4 (3:1)* & 13,47 & 42,75 & 43,78 & 208,76 \\
F5 $(1: 0)^{*}$ & 13,52 & 42,22 & 44,26 & 211,59 \\
\hline
\end{tabular}

Keterangan : * = Penambahan tepung kedelai : tepung kacang hijau

$\mathrm{a}=$ berdasarkan Zoumas et al. (2002) $\mathrm{b}=$ target kalori food bars labu kuning.

Tabel 7 Hasil Uji Kesukaan terhadap Parameter Warna, Rasa, Aroma, Teksur dan Overall Food Bars Labu Kuning

\begin{tabular}{llllll}
\hline Sampel & Warna & Rasa & Aroma & Tekstur & Overall \\
\hline F1 $(0: 1)^{*}$ & $4,37^{\mathrm{b}}$ & $3,06^{\mathrm{a}}$ & $3,71^{\mathrm{a}}$ & $4,31^{\mathrm{bc}}$ & $3,46^{\mathrm{a}}$ \\
F2 $(1: 3)^{*}$ & $3,20^{\mathrm{a}}$ & $3,09^{\mathrm{a}}$ & $3,49^{\mathrm{a}}$ & $4,23^{\mathrm{bc}}$ & $3,03^{\mathrm{a}}$ \\
F3 $(1: 1)^{*}$ & $4,51^{\mathrm{b}}$ & $4,00^{\mathrm{b}}$ & $4,17^{\mathrm{ab}}$ & $3,26^{\mathrm{a}}$ & $4,34^{\mathrm{bc}}$ \\
F4 $(3: 1)^{*}$ & $4,40^{\mathrm{b}}$ & $4,49^{\mathrm{bc}}$ & $4,71^{\mathrm{bc}}$ & $4,17^{\mathrm{b}}$ & $4,23^{\mathrm{b}}$ \\
F5 $(1: 0)^{*}$ & $5,31^{\mathrm{c}}$ & $4,83^{\mathrm{c}}$ & $4,91^{\mathrm{c}}$ & $4,94^{\mathrm{c}}$ & $4,97^{\mathrm{c}}$ \\
\hline
\end{tabular}

Keterangan : Nilai yang diikuti huruf yang berbeda pada kolom yang sama menunjukkan nilai yang berbeda nyata pada taraf signifikansi 0,05 . Semakin tinggi nilai maka semakin tinggi tingkat kesukaan panelis. * = Penambahan tepung kedelai : tepung kacang hijau

cenderung lebih gelap daripada keempat sampel lainnya karena tingginya kandungan protein pada sampel F5. Semakin tinggi kandungan protein pada food bars labu kuning maka pencoklatan yang terjadi karena reaksi maillard akan semakin banyak sehingga produk yang dihasilkan akan semakin gelap.

\section{Rasa}

Pada Tabel 7 tingkat kesukaan panelis terhadap parameter rasa paling rendah dimiliki oleh sampel F1 dan paling tinggi dimiliki oleh sampel F5. Dari hasil analisis statistik diketahui bahwa sampel F1 berbeda nyata dengan sampel F5. Hal ini menunjukkan panelis lebih menyukai rasa food bars labu kuning dengan penambahan tepung kedelai daripada food bars labu kuning dengan penambahan tepung kacang hijau. Hal ini disebabkan pada sampel F1 jumlah gula yang digunakan lebih sedikit daripada keempat sampel lainnya. Selain itu penggunaan tepung kacang hijau menimbulkan rasa langu yang tidak disukai panelis. Semakin sedikit jumlah penggunaan tepung kacang hijau pada food bars labu kuning maka semakin tinggi tingkat kesukaan panelis terhadap parameter rasa food bars labu kuning.

\section{Aroma}

Pada Tabel 7 tingkat kesukaan panelis terhadap parameter aroma paling rendah dimiliki oleh sampel F2 dan paling tinggi dimiliki oleh sampel F5. Selain dihasilkan oleh aroma khas susu dan aroma khas labu kuning, aroma food bars labu kuning juga dipengaruhi oleh penambahan tepung kacang hijau dan tepung kedelai. Aroma langu yang terdapat pada tepung kacang hijau dapat ditemukan pada food bars labu kuning dengan penambahan tepung kacang hijau yaitu sampel F1, F2, F3, dan F4. Sedangkan pada aroma sampel F5 yang tidak menggunakan tepung kacang hijau dan hanya menggunakan tepung kedelai tidak ditemukan aroma langu. Dengan adanya 
aroma langu pada sampel F1, F2, F3, dan F4 maka tingkat kesukaan panelis terhadap keempat sampel tersebut menjadi lebih rendah daripada sampel F5.

\section{Tekstur}

Pada Tabel 7 tampak bahwa tekstur yang paling disukai panelis adalah tekstur sampel F5. Sedangkan tekstur yang paling tidak disukai panelis adalah tekstur sampel F3. Pada Tabel 4 diketahui bahwa tingkat kekerasan food bars labu kuning yang paling tinggi yaitu pada sampel F4 sedangkan tingkat kekerasan yang paling rendah pada sampel F1. Dari kedua data tersebut diketahui bahwa tingkat kesukaan panelis terhadap parameter tekstur tidak dipengaruhi oleh tingkat kekerasan food bars labu kuning. Produk dengan tingkat kekerasan tinggi sehingga tidak mudah patah tidak terlalu disukai panelis karena menimbulkan kesan sulit digigit.

\section{Overall}

Pada Tabel 7 tampak bahwa tingkat kesukaan panelis terhadap parameter overall sampel F1 dan sampel F2 tidak berbeda nyata, begitu juga tingkat kesukaan panelis terhadap parameter overall sampel F3 dan F4 serta sampel F3 dan F5, namun ketiganya memiliki nilai yang berbeda nyata. Tingkat kesukaan panelis terhadap parameter overall sampel F5 memiliki nilai yang paling tinggi dibanding keempat sampel lainnya. Hal ini menunjukkan food bars labu kuning yang paling disukai panelis adalah food bars labu kuning dengan perbandingan penambahan tepung kedelai dan tepung kacang hijau 1:0 yang mempunyai warna gelap, tidak ada rasa dan aroma langu, serta memiliki tekstur yang tidak terlalu keras.

\section{Aftertaste Langu}

Tabel 8 menunjukkan bahwa intensitas aftertaste langu yang paling besar yaitu pada sampel F2 sedangkan intensitas aftertaste langu yang paling kecil yaitu pada sampel F5 dan nilai keduanya berbeda nyata. Dari data tersebut diketahui bahwa semakin banyak penambahan tepung kedelai maka intensitas aftertaste langu yang berasal dari rasa tepung labu kuning semakin sedikit. Pada formulasi sampel F1 tidak digunakan tepung kedelai, namun intensitas aftertaste langu lebih kecil daripada sampel F2 yang menggunakan penambahan tepung kacang hijau dan tepung kedelai dengan perbandingan 3:1. Hal ini disebabkan karena pada formulasi sampel F1 penggunaan tepung labu kuning lebih sedikit daripada sampel F2.

Tabel 8 Hasil Uji Pembedaan terhadap Paremeter Aftertaste Langu Food Bars Labu Kuning

\begin{tabular}{ll}
\hline Sampel & Aftertaste langu \\
\hline F1 $(0: 1)^{*}$ & $0,38^{\mathrm{c}}$ \\
F2 $(1: 3)^{*}$ & $0,68^{\mathrm{d}}$ \\
F3 $(1: 1)^{*}$ & $0^{\mathrm{b}}$ \\
F4 $(3: 1)^{*}$ & $-0,26^{\mathrm{b}}$ \\
F5 $(1: 0)^{*}$ & $-0,81^{\mathrm{a}}$ \\
\hline
\end{tabular}

Keterangan : Nilai yang diikuti huruf yang berbeda pada kolom yang sama menunjukkan nilai yang berbeda nyata pada taraf signifikansi 0,05 . Semakin rendah nilai maka semakin rendah intensitas aftertaste langu yang dirasakan panelis

* = Penambahan tepung kedelai : tepung kacang hijau

\section{KESIMPULAN DAN SARAN}

\section{Kesimpulan}

1. Food bars labu kuning yang memenuhi standar gizi pangan darurat dan memiliki tingkat penerimaan konsumen paling tinggi adalah food bars labu kuning dengan perbandingan penambahan tepung kedelai dan tepung kacang hijau 1:0 dengan komposisi tepung labu kuning 31,25\%, susu bubuk full cream $13,02 \%$, gula pasir $7,81 \%$, margarin $14,06 \%$, air $13,02 \%$ dan tepung kedelai $20,83 \%$.

2. Food bars labu kuning dengan perbandingan penambahan tepung kedelai dan kacang hijau 1:0 memiliki tingkat kekerasan dengan Fmax 20,95 N, kadar air 14,76\%, kadar abu 4,28\%, kadar protein 14,31\%, kadar lemak 19,87\% dan kadar karbohidrat 46,78\% dengan total kalori 211,56 kkal/50 g yang terdiri dari $13,52 \%$ protein, $42,22 \%$ lemak dan 44,26\% karbohidrat. Berdasarkan analisis organoleptik, food bars labu kuning dengan perbandingan 
penambahan tepung kedelai dan tepung kacang hijau 1:0 memiliki warna gelap, tidak ada rasa dan aroma langu, memiliki tekstur yang tidak terlalu keras serta tidak mempunyai aftertaste langu.

\section{Saran}

Perlu dilakukan penelitian lebih lanjut mengenai pendugaan umur simpan untuk mengetahui umur simpan food bars labu kuning sebagai produk pangan darurat.

\section{DAFTAR PUSTAKA}

Astawan, Made. 2009. Sehat dengan Hidangan Kacang dan Biji-Bijian. Penebar Swadaya, Depok

Gaman, P.P., and Sherrington, K. B. 1981. Ilmu Pangan, Pengantar Ilmu Pangan, Nutrisi dan Mikrobiologi. UGM Press. Yogyakarta

Nio, Oey Kam. 1992. Daftar Analisis Bahan Makanan. Balai Penerbit Fakultas Kedokteran Universitas Indonesia, Jakarta

Robinson, Corinne H. 1975. Basic Nutrition and Diet Therapy. Macmillan Publishing Co Inc. Oxford

Setyaningsih, Dwi., Anton Ariyantono, Maya Puspita S. 2010. Analisis Sensori. IPB Press, Bogor

Shemilt, LW. 1983. Chemistry and World Food Supplies: The New Frontiers CHEMRAWN II (Chemical Research
Applied to World Needs). Pergamon press. Oxford

Sudarmadji, Slamet., Bambang Haryono, Suhardi. 1989. Analisa Bahan Makanan dan Pertanian. Liberty, Yogyakarta

Tejasari. 2005. Nilai Gizi Pangan. Graha Ilmu, Yogyakarta

Widjanarko, Simon B. 2008. Pangan Darurat (Food Bars) Berenegi Tinggi Menggunakan Tepung Komposit (Tepung Gaplek, Tepung Kedelai, Tepung Terigu) dan Tepung Porang (Amorphophallus oncophyllus) atau Konjac Flour. www.simonbwidjanarko.wordpress.co m. Diakses pada tanggal 2 Januari 2012

Widowati, S., N. Richana, Suarni, P. Raharto dan I.G.P. Sarasutha. 2001. Studi Potensi dan Peningkatan Daya Guna Sumber Pangan Lokal untuk Penganekaragaman Pangan di Sulawesi Selatan. Laporan Hasil Penelitian Puslitbangtan. Bogor

Zoumas, B.L., L.E. Armstrong, J.R. Backstrand., W.L. Chenoweth., P. Chinachoti, B. P. Klein, H. W. Lane. K. S. Marsh., M. Tolvanen. 2002. HighEnergy, Nutrien-Dense Emergency Relief Food Product. Food and Nutrition Board : Intitute of Medicine. National Academy Press, Washington DC. 